\title{
Testing for a Break in the Persistence in Yield Spreads of EMU Government Bonds
}

\author{
Philipp Sibbertsen ${ }^{\mathrm{a}, *}$, Christoph Wegener ${ }^{\mathrm{a}, \mathrm{b}}$, Tobias Basse $^{\mathrm{b}, \mathrm{c}}$ \\ ${ }^{a}$ Institute of Statistics, Leibniz Universität Hannover, Königsworther Platz 1, 30167 \\ Hannover, Germany \\ ${ }^{b}$ Norddeutsche Landesbank Girozentrale, Friedrichswall 10, 30159 Hannover, Germany \\ ${ }^{c}$ Touro College Berlin, Am Rupenhorn 5, 14055 Berlin, Germany
}

\begin{abstract}
This study tests for a break in the persistence of EMU government bond yield spreads examining data from France, Italy and Spain and using German interest rates as a kind of benchmark. The results reported here provide evidence for breaks between 2006 and 2008. The persistence of the yield spreads against German government bonds has increased significantly after this period. This could be a sign of higher sovereign credit risk (and possibly even redenomination risk) caused by the debt crisis in the euro area. We find long-memory behavior before and after the breakpoints and empirical evidence for positive excess kurtosis and GARCH-effects when persistence increases.
\end{abstract}

Keywords: Testing Uncovered Interest Parity; Fractional integration; Changing persistence

JEL: C22; E43; G12

\footnotetext{
${ }^{*}$ Corresponding author. Fone: +49(0)511 7623783 Fax: +49(0)511 7623923

Email addresses: sibbertsen@statistik.uni-hannover.de (Philipp Sibbertsen), christoph.wegener@nordlb.de (Christoph Wegener), tobias.basse@nordlb.de (Tobias Basse)
} 


\section{Introduction}

The sovereign debt crisis in the euro area has had major consequences for European bond markets. Already before the Greek debt swap was implemented, the difficult fiscal situation in some member countries caused concerns among investors about increasing sovereign credit risk. The losses, forced on all private sector lenders holding Greek local law bonds, intensified these worries. Now there exists even redenomination risk due to fear of a potential end of the Euro. The return of exchange rate risk after the end of a currency union or some other system of fixed exchange rates can indeed be of some importance for financial markets. While the literature has not focused too strongly on historical experiences with exits from currency unions, Rose (2007) has documented quite a number of cases after the end of World War II. Moreover, there is also a vivid discussion on the breakdown of the Bretton Woods system (e.g., Cooper, 1984; Basse, 2006). As a consequence of the crisis in Europe, the low yield spreads among government bonds issued by the member states of the European Monetary Union (EMU) - which mainly were a result of the introduction of the common currency - now seem to be a phenomenon of happier times. In fact, creditors now have started to distinguish clearly between the different member states of the euro area. We use techniques of time series analysis to examine how sovereign credit risk and redenomination risk have affected government bond yields in the euro area. While we do not use the classical event study methodology our approach still focuses on timing issues by searching for structural breaks in

yield differentials. The paper examines data on interest rates from the four economically most important member states of the euro area (namely France, 
Germany, Italy and Spain). Following Lund (1999) and Basse, Friedrich and Kleffner (2012) we use German government bond yields as some kind of benchmark because this country is generally assumed to follow a relatively prudent fiscal policy. Baum and Barkoulas (2006) have shown that there could be fractional cointegration among European government bond yields. Therefore, we employ a new test procedure recently proposed by Sibbertsen and Kruse (2009) which allows for fractional integration to test for constant persistence behavior of the spreads.

The paper is structured as follows: The 2nd section gives a brief review of the relevant literature. Section 3 then introduces the data examined and also discusses some methodological issues. Before concluding in the 5th section the results of our empirical investigations are reported and discussed in section 4 .

\section{Literature Overview}

Since the introduction of the Euro in 1999 empirical research examining interest rate convergence in Europe has become very popular. However, there exist even earlier papers considering this matter. In fact, the last three decades have witnessed the publication of a vast number of empirical studies examining the relationship among interest rates in Europe. Given that Pigott (1993) has provided a widely cited overview of numerous issues

related to international interest rate convergence including a discussion of the earlier empirical evidence documented in the literature, this overview will focus mainly on more recent empirical studies.

Most important for the empirical analysis presented in this paper, Lund 
(1999) has suggested to use German interest rates as a kind of benchmark in applied econometric work examining interest convergence in the euro area. His paper is one of the many empirical studies that is based on the assumption that the introduction of the Euro has increased the integration of EMU bond markets. Basically, Lund (1999) has argued that the advent of the common European currency has eliminated the exchange rate risk for investors buying fixed income securities issued by other EMU countries and that the Euro already ought to have affected the relationship among interest rates before 1999 because a binding time table for the introduction of the new currency was already presented in late 1991. Focussing on yield spreads to German government bonds he has calculated "EMU probabilities" for many European countries and essentially has documented a 100\% probability of EMU membership for France and the Benelux countries since 1995. Interestingly, bond markets were less optimistic with regard to Italy, Spain, and Portugal. As a matter of fact, according to Lund (1999) the "EMU probabilities" for these countries were rather low until late 1996. More recently, Frömmel and Kruse (2009) have reported similar findings, analyzing the interest rate differentials of 3 months treasury bill rates from Belgium, France, Italy and the Netherlands with Germany as the reference country examining data from 1983 to 2007. They have tested for a break in persistence in the classical $I(0) / I(1)$ framework and found breaks from $I(1)$ to $I(0)$ for Belgium, France and Italy between May 1995 and December 1998.

Many econometricians have also examined data before 1990 arguing that the Exchange Rate Mechanism (ERM) of the European Monetary System (EMS) already could have caused convergence of interest rates in Europe 
(e.g., Siklos and Wohar, 1997; Baum and Barkoulas, 2006). Because of this institutional arrangement - with reducing exchange rate risk - German government bond yields ought to have played a special role for the European bond markets thereby "causing" interest rate movements in other ERM countries. This assumption is the so-called German Dominance Hypothesis. Generally speaking, testing this hypothesis has produced mixed empirical findings. Hassapis, Pittis and Prodromidis (1999), for example, have noted that the ERM did not strongly increase the linkage between interest rates in Germany and the rates of other ERM member states. Only the Netherlands seem to be an exception. This is probably no surprise because already back then, monetary policymakers in the Netherlands were trying to imitate the strategies of the Deutsche Bundesbank. In fact, other empirical studies have also reported a strong relationship between Dutch and German interest rates (e.g., De Haan, Pilat and Zelhorst, 1991; Kanas, 1997).

Nevertheless, there exist also some empirical evidence supporting the German Dominance Hypothesis to an even stronger degree. Most important, Baum and Barkoulas (2006) recently have used techniques of fractional cointegration analysis to test the German Dominance Hypothesis and have reported results supporting this theory. Bajo-Rubio and Montávez-Garcés (2002) have argued that their results do show that Germany played a special role in the ERM. Interestingly, they have documented hardly any evidence for structural change affecting the estimated relationships among different interest rates in ERM countries. However, Fountas and Wu (1998) have noted that the presence of structural breaks is of some importance and that there is clear empirical evidence for interest rate convergence in the period from 
1979 to 1995. Additionally, Siklos and Wohar (1997) have reported some empirical evidence for interest rate convergence among ERM countries during specific periods of time. More recently, the advent of the Euro has revived the debate about interest rate convergence in Europe. Laopodis (2008), for example, has reported an increase in the correlation of the returns on Euro government bonds after the introduction of the common currency, examining data from 10 EMU countries. Employing techniques of cointegration analysis, Laopodis (2008) also has identified two groups of EMU countries - a core group of members (including Germany and France) and a number of peripheral countries (including Italy and Ireland). Additionally, a graphical analysis by Kočenda, Kutan and Yigit (2006) seems to confirm that the interest rates in the new EU countries do converge to the interest rates in the core countries.

More recently, Jenkins and Madzharova (2008) have reported that cointegration among nominal interest rates in the Euro area is a phenomenon of economic relevance after the introduction of the common currency. As will be discussed later on, this empirical finding does imply the existence of a strong long-term equilibrium among bond yields and does indicate that interest rates have converged. Interestingly, real interest rates do not seem to be cointegrated according to these authors. Basse, Friedrich and Kleffner (2012) have focused on government bond yields in Germany and Italy and have reported that there is empirical evidence for cointegration with two structural breaks using techniques of bi-variate cointegration analysis. They have argued that the first breakpoint was caused by the US subprime crisis and that the second break seems to be a result of the increase of Italian sovereign 
credit risk (and probably even redenomination risk) caused by the current crisis in Europe. In fact, the sovereign debt crisis in Europe seems to be of major importance for bond markets in the Euro area. Apergis, Mamatzakis and Staikouras (2011), for example, have reported that the spreads of Greek government bond yields over swaps and CDSs are cointegrated and that two regimes can be identified. They have estimated a threshold vector errorcorrection model and have argued that their results indicate that adjustment costs are of economic relevance (at least in the short run). Moreover, a paper by Melander et al. (2011) applies Consistent Information Multivariate Density Optimizing Methodology (CIMDO) using CDS spreads to assess the market beliefs of contagion between sovereigns and banks in Western Europe (e.g. France and Germany), euro area periphery (e.g. Greece and Ireland) and emerging Europe (e.g. Poland and Turkey). The authors show that Western European countries were less vulnerable to contagion from Ireland and Greece than other countries from emerging Europe and the euro area periphery. Another interesting result is that Greece seems to be less contagious than Ireland.

\section{Data and Methodology}

We examine bond yields from Germany, Italy, Spain and France with maturities of five, seven and ten years. The weekly data from 2002-01-04 to 2012-08-24 are taken from Bloomberg. The time series are generic interest rates based on bid prices of the relevant government bonds. According to the unit root tests reported in table A.1 all yields seem to be integrated of order $1(I(1))$. This is no surprise at all. In fact, many empirical studies have 
reported that interest rates in developed countries are $I(1)$ variables (e.g., Siklos and Wohar, 1997; Kleimeier and Sander, 2000).

\section{(Insert Table A.1 here)}

As already indicated, sovereign credit risk and redenomination risk are of central importance for this study. Both types of risk clearly have the potential to end the process of interest rate convergence that used to characterize the interest rate environment in the Euro area since (and already before) the introduction of the European common currency. Becker and Hall (2007) have noted that cointegration is in general a useful operational definition of convergence for non-stationary time series. With regard to interest rates, Camarero, Ordonez and Tamarit (2002) have identified two different levels of convergence of interest rates in different countries: catching-up and long-run convergence. They have argued that long-run convergence describes a strong relationship between the variables examined and implies the absence of a time trend in the deterministic process. Major changes to the market's view of sovereign credit risk of one country clearly could affect the relationship among the bond yields examined. Additionally, the uncovered interest parity hypothesis (which is a key concept to the analysis of currency risk) also provides a theoretical basis for assuming that a cointegration relation between the bond yields from two countries should exist under certain circumstances. Assuming that there is no credit risk and that the fixed income securities examined are very similar with regard to their liquidity, of course, exchange rate risk is of central importance.

The uncovered interest parity 


$$
i_{t}-i_{t}^{*} \approx \frac{E\left[\Delta S_{t+1}\right]}{S_{t}}+\phi_{t}
$$

provides a theoretical cointegration relation between the bond yields of two countries $i_{t}$ and $i_{t}^{*}$ (see Taylor, 1995; Flood and Rose, 2002). Testing the uncovered interest parity theory is an almost classical problem of cointegration analysis (see Johansen and Juselius, 1992). In equation $1 \phi_{t}$ denotes a risk premium, $S_{t}$ is the exchange rate between the two countries and $E_{t}\left[\Delta S_{t+1}\right]$ is the expected change of the exchange rate. All variables are depending on time t. The exchange rate should be an $I(1)$ variable. Therefore, the expected relative change has to be $I(0)$. Given our assumptions about bond markets, the risk premium is only a compensation for currency risk. Consequently, this variable should not only be stationary but also equal to 0 when market participants have no reason to voice doubts about the stability of the euro area. Thus, assuming the bond yields as $I(1)$ and the right handside of equation 1 as $I(0)$ requires a cointegration relation between $i_{t}$ and $i_{t}^{*}$. Therefore the cointegrating vector for $i_{t}$ and $i_{t}^{*}$ should read $\beta=(1,-1)$. Cointegration describes a long-term equilibrium between two or more $I(1)$-variables $y_{t}$. This means that these variables share common stochastic trends thus there exists a stationary $(I(0))$ linear combination $\beta^{\prime} y_{t}=z_{t}$. Using spectral analysis and Granger causality tests, Kirchgässner and Wolters (1987) have investigated the linkages among interest rates in the United States and West Germany. They have shown that a strong relationship between these time series existed in the period from 1979 to 1984 but no or only a weak linkage from 1974 to 1978 . 
However we want to check whether the long-term relationship between the EMU government bond yields is constant since a break in the persistence of the spreads could be interpreted as a change in the time series properties of the risk premia. In fact, Johansen and Juselius (1992) already have argued that the existence of a risk premium could cause some problems when testing the uncovered interest rate theory using techniques of cointegration analysis. Leybourne, Kim, Smith and Newbold (2003) constructed a test in the classical $I(0) / I(1)$ framework under the null hypothesis that the process is $I(1)$ up to a break to $I(0)$. They also showed that the test has power in the case of a break from $I(0)$ to $I(1)$ or even when the variable is $I(0)$. As already discussed, Frömmel and Kruse (2009) used this test to analyze interest rate convergence in the European Monetary System (EMS) prior to the EMU. However Baum and Barkoulas (2006) demonstrated that EMU interest rate spreads exhibit long-memory behavior. Sibbertsen and Kruse (2009) modified the test by Leybourne, Taylor and Kim (2007) to allow for long memory dynamics. Under the null hypothesis of this test there is no change in the persistence against the alternative that the persistence breaks from $0 \leq d<\frac{1}{2}$ to $\frac{1}{2} \leq d<\frac{3}{2}$ or vice versa. Furthermore, the authors showed that this test has good power and a breakpoint estimator works satisfactorily.

Sibbertsen and Kruse (2009) have assumed that the data generating process follows an $\operatorname{ARFIMA}(p, d, q)$ process as proposed by Granger and Joyeux (1980):

$$
\Phi(B)(1-B)^{d} z_{t}=\Psi(B) \epsilon_{t},
$$

where $\epsilon_{t}$ is white noise and all roots of the polynomials $\Phi(B)$ and $\Psi(B)$ are assumed to lie outside the unit circle. The long-memory parameter $d$ 
determines the degree of integration. So Sibbertsen and Kruse (2009) have formulated the hypothesis as

$$
H_{0}: d=d_{0}, \forall t \text { vs. } H_{1}:\left\{\begin{array}{l}
d=d_{1} \text { for } t=1, \ldots,[\tau T] \\
d=d_{2} \text { for } t=[\tau T]+1, \ldots, T
\end{array}\right.
$$

with $[x]$ as the biggest integer smaller than $x$. They restricted $d$ under the null hypothesis as $0 \leq d_{0}<\frac{3}{2}$ and under the alternative as $0 \leq d_{1}<\frac{1}{2}$ and $\frac{1}{2} \leq d_{2}<\frac{3}{2}$. An important advantage of this test is, that $d_{1}$ and $d_{2}$ can be exchanged, thus a break of persistence from stationarity to $I(1)$ and vice versa can be examined. Furthermore, the test statistic proposed by Leybourne, Taylor and Kim (2007) reads

$$
R=\frac{\inf _{\tau \in \Lambda} K^{f}(\tau)}{\inf _{\tau \in \Lambda} K^{r}(\tau)}
$$

with the CUSUM of squares-based statistics using the forward

$$
K^{f}(\tau)=[\tau T]^{-2 d_{0}} \sum_{t=1}^{[\tau T]} \hat{v}_{t, \tau}^{2}
$$

and the reverse residuals

$$
K^{r}(\tau)=(T-[\tau T])^{-2 d_{0}} \sum_{t=1}^{T-[\tau T]} \hat{v}_{t, \tau}^{2}
$$

where $\hat{v}_{t, \tau}$ denotes the residuals of a OLS regression using the observations up to $[\tau T]$ of $z_{t}$ on 1 for all $t$. The relative breakpoint is denoted as $\tau \in \Lambda$ with $\Lambda \subset(0,1)$. The authors showed that the breakpoint estimator proposed by 
Leybourne, Taylor and Kim (2007) is consistent in the case of long memory. Denoting the true breakpoint as $\tau_{0}$, in the case of a break from $I(1)$ to stationary long memory Sibbertsen and Kruse (2009) showed that

$$
\hat{\tau}^{f}=\arg \inf _{\tau \in \Lambda} K^{f}(\tau)
$$

is a consistent estimator. In the case of a break from stationary to nonstationary long memory

$$
\hat{\tau}^{r}=\arg \inf _{\tau \in \Lambda} K^{r}(\tau)
$$

is consistent. The asymptotic properties and the results of a Monte Carlo study are presented in detail by Sibbertsen and Kruse (2009).

\section{Results}

To estimate $d$ under $H_{0}$ within the procedure suggested by Sibbertsen and Kruse (2009) we use the semi-parametric method proposed by Geweke and Porter-Hudak (1983) and a full parametric maximum likelihood estimator for the $\operatorname{ARFIMA}(p, d, q)$ model. The test results are reported in table A.2.

(Insert Table A.2 here)

If the diagnostics indicate a generalized autoregressive conditional heteroscedasticity (GARCH) term we employ a GARCH or GJR-GARCH model by Glosten, Jagannathan and Runkle (1993). The test statistics and the $p$ values of the Ljung-Box test applied to the (squared) residuals $Q(p)\left(Q^{2}(p)\right)$ and the ARCH-LM test are reported in table A.3 to A.5; $p$ indicates the lag-lengths and the $p$-values are displayed in parentheses. 
(Insert Table A.3 here)

(Insert Table A.4 here)

(Insert Table A.5 here)

Furthermore we consider the Normal (norm) and the Student-t (std) distribution for the residuals. The $\operatorname{ARFIMA}(p, d, q)-\operatorname{GARCH}(1,1)$ approach takes GARCH effects directly into account while the GPH estimator is quite robust against this (see Hauser, 1997). Moreover, the ARFIMA model is also able to consider $\operatorname{AR}(p)$ and $\operatorname{MA}(q)$ parts and is expressed by equation (2). In the case of an $\operatorname{ARFIMA}(p, d, 0)-\operatorname{GARCH}(1,1)$ model the equation is given by

$$
\begin{gathered}
\Phi(B)(1-B)^{d} z_{t}=\mu+\epsilon_{t} \\
\epsilon_{t} \sim\left(0, h_{t}\right) \\
h_{t}=\omega+\alpha \epsilon_{t-1}^{2}+\beta h_{t-1}
\end{gathered}
$$

or in the case of the GJR-GARCH model by

$$
h_{t}=\omega+\alpha \epsilon_{t-1}^{2}+\beta h_{t-1}+\delta \epsilon_{t-1}^{2} I_{t-1}
$$

where $I_{t-1}=0$ if $\epsilon_{t-1} \geq 0$ and $I_{t-1}=1$ if $\epsilon_{t-1}<0$. With regard of simplification we restrict the MA part as $q=0$. Despite the disadvantages of the GPH estimator compared to the $\operatorname{ARFIMA}(p, d, q)-(\operatorname{GARCH}(1,1))$ model, we 
also consider both approaches to check the robustness of our results. Also Frömmel and Kruse (2012) used this procedure to test for a rational bubble under long memory considering the S\&P500 dividend-price ratio. Furthermore, another study by Cuñado, Gil-Alana and De Gracia (2005) employed methodology based on fractional processes to test for bubbles in the NASDAQ stock market index.

We specify the set of potential breakpoints as $\Lambda=[0.1 T, 0.9 T]$ and we use de-meaned data. The lag-lengths of the $\operatorname{ARFIMA}(p, d, q)-(\operatorname{GARCH}(1,1))$ models are determined by the Schwarz criterion. After considering the optimal $p$, we obtain no satisfying diagnostic results in some cases. So we reduce the lag-lengths and receive correctly specified models. Also deterministic trends are taken into account. However, they are not significant (results are not reported in order to conserve space). The bandwidth of the GPH estimator is set to the MSE optimal rate $\left(T^{\frac{4}{5}}\right)$ and the one proposed by Geweke and Porter-Hudak (1983) $\left(T^{\frac{1}{2}}\right)$.

All results of the test by Sibbertsen and Kruse (2009) are reported in table A.2. The empirical results documented here seem to imply that in the majority of cases there are indications for structural change occurring in early 2008. This break date can be explained quite easily. In fact, the US subprime crisis seems to have caused concerns about public finances in some EMU member states (e.g. Ireland and Greece). Martin and Waller (2012, pg. 331), for example, have noted: "The fiscal situation in several euro area countries has deteriorated significantly since 2008." These worries may also be related to costly bank rescue programmes. Moreover, investors became extremely risk averse searching for secure financial assets ('flight to 
quality'). This tendency of probably even excessive risk avoidance increased the demand for German government bonds. Therefore, German interest rates were falling while government bond yields in the periphery countries went up. Meanwhile, the European government debt crisis has intensified the concerns about sovereign credit risk in some parts of the Euro area. Interestingly, Basse, Friedrich and Kleffner (2012) who have examined Italian and German government bond yields have also reported empirical evidence indicating the existence of a structural break in 2008. They have used a completely different methodology. Therefore, the year 2008 obviously seems to have brought about some major changes affecting the European government bond market. Phrased somewhat differently, sovereign credit risk (and probably even redenomination risk) today is of special importance for investors. These results are quite robust since $d$ increases in the case of the ARFIMA model and the GPH-estimator (see table A.6).

\section{(Insert Table A.6 here)}

(Insert Figure B.1 here)

Interestingly, the spreads (see figure B.1) also seem to show non-stationary long-memory behavior in the first regime. This finding is not compatible with a restrictive interpretation of the uncovered interest rate parity (which means equation (1)) assuming that there is no currency or sovereign credit risk and that the bonds examined are homogenous. Under these circumstances economic theory would indeed predict that the spreads in the first regime should be $I(0)$. 
However, even without sovereign credit risk or redenomination risk the existence of a liquidity premium could help to explain the empirical results reported above. In fact, this might be a reason why $d$ is quite low in the case of France since the liquidity of both the German and the French government bond market is very high. Moreover, the finding that $d$ has significantly increased in all cases examined here can be explained by the fact that markets now have started to fear sovereign credit risk and probably even redenomination risk. So, the rising credit (and probably redenomination) risk causes increasing persistence. Moreover, there are additional interesting effects. Considering table A.3 up to table A.5 the increasing persistence is accompanied by GARCH effects and positive excess kurtosis. So the test decision might be affected by the aforementioned properties. As a matter of fact, Heinen, Sibbertsen and Kruse (2009) have noted that the size and power of the test suggested by Sibbertsen and Kruse (2009) is nearly unaffected by GARCH disturbances. Also the breakpoint estimator is not influenced by GARCH effects. See figure B.2 for the $d$ times differentiated spread series (we use the estimated $d$ from the ARFIMA approach).

(Insert Figure B.2 here)

Considering the results in the tables A.3 to A.5 again: Until the breakpoint the pure ARFIMA models assuming a normal distribution for the innovations work quite well. When the persistence of the spread breaks, an ARFIMA model with GARCH extension and Student-t distribution is superior to the simple model. Unsurprisingly, rising credit risk also seems to cause volatility clustering and positive excess kurtosis. Thus, when the 
spreads start to move strongly the tails of the distributions become heavier and the volatilities are higher for some periods of time. This might be caused by herding behavior of bond investors. With regard to the model fit, an asymmetric GARCH model seems to be a good empirical modelling strategy in the case of the yield spreads of German and Spanish 5 years bonds. This can be interpreted as follows: The volatility of the spread increases more strongly, when investors get more concerned about the fiscal situation in Spain.

Summing up, the crisis seems to have affected European government bond yield spreads significantly. There is long-memory behavior before and after the breakpoints and empirical evidence for GARCH effects and positive excess kurtosis when the persistence increases.

\section{Conclusion}

The results reported above do seem to illustrate quite clearly that the current sovereign debt crisis in the euro area does affect the relationship among government bond yields in the countries examined. Most important, there is empirical evidence for structural change affecting the yield spreads among sovereign debt issued by Germany and the three other major member countries of the Euro area. The temporal characteristics of interest rate differentials now seem to be different. In fact, the grade of integration of the time series examined here during the crisis now is closer to $I(1)$ than to $I(0)$. These findings do indicate that financial markets, pricing government debt in the euro area meanwhile focus more strongly on sovereign credit risk - and possibly even redenomination risk. Our results do have some implications: 
Most important, taking a political perspective there now seem to be real fears that the European monetary union could break apart. These worries might have consequences for financial markets. Risk managers in financial institutions, for example, now should be aware that German and Spanish government bonds are no perfect substitutes anymore. Moreover, looking at things from a totally different perspective, the higher government bond yields increase the funding costs of some European governments and therefore certainly can have negative effects on the sustainability of the debt of these countries. 


\section{Appendix A. Tables}

Table A.1: Results of the ADF test

\begin{tabular}{rrrr}
\hline \hline Italy & Lags & ADF & p-Value \\
\hline \hline Germany & & & \\
5 Years & 1 & -1.529 & 0.129 \\
7 Years & 1 & -1.6203 & 0.09995 \\
10 Years & 1 & -1.6111 & 0.1028 \\
\hline Italy & & & \\
5 Years & 1 & -0.3869 & 0.493 \\
7 Years & 1 & -0.2787 & 0.5275 \\
10 Years & 1 & -0.0984 & 0.585 \\
\hline Spain & & & \\
5 Years & 2 & -0.2827 & 0.5262 \\
7 Years & 2 & 0.0146 & 0.621 \\
10 Years & 2 & 0.2314 & 0.6901 \\
\hline France & & & \\
5 Years & 1 & -1.4586 & 0.1514 \\
7 Years & 1 & -1.4309 & 0.1603 \\
10 Years & 1 & -1.4008 & 0.1699 \\
\hline \hline
\end{tabular}

The table reports the results of the ADF test applied to government bonds yields in levels. 
Table A.2: Results of the test against changing persistence

\begin{tabular}{|c|c|c|c|c|c|c|c|}
\hline & & $\overline{c d}$ & Test Statistic & $\begin{array}{r}\text { CV low } \\
0.05 / 0.1 \\
\end{array}$ & $\begin{array}{r}\text { CV up } \\
0.05 / 0.1 \\
\end{array}$ & Test Decision & Break Date \\
\hline \multicolumn{8}{|l|}{ Italy } \\
\hline \multirow[t]{3}{*}{5 Years } & $G P H_{0.5}$ & $\begin{array}{r}0.7712644 \\
(0.00)\end{array}$ & \multirow[t]{3}{*}{0.1557363} & 0.4274355 & 2.285243 & Increasing & \multirow[t]{3}{*}{$2007-12-14$} \\
\hline & $G P H_{0.8}$ & $\begin{array}{r}1.017856 \\
(0.00)\end{array}$ & & 0.2182672 & 4.495146 & Increasing & \\
\hline & $A R F I M A$ & $\begin{array}{r}0.954852 \\
(0.00) \\
\end{array}$ & & 0.2640724 & 3.787776 & Increasing & \\
\hline \multirow[t]{3}{*}{7 Years } & $\overline{G P H_{0.5}}$ & $\begin{array}{r}0.8269553 \\
(0.00)\end{array}$ & \multirow[t]{3}{*}{0.1418838} & 0.3731062 & 2.696331 & Increasing & \multirow[t]{3}{*}{$2008-05-16$} \\
\hline & $G P H_{0.8}$ & $\begin{array}{r}1.016441 \\
(0.00)\end{array}$ & & 0.2192353 & 4.476367 & Increasing & \\
\hline & $A R F I M A$ & $\begin{array}{r}0.93935 \\
(0.00) \\
\end{array}$ & & 0.2761654 & 3.643303 & Increasing & \\
\hline \multirow[t]{4}{*}{10 Years } & $\overline{G P H_{0.5}}$ & $\begin{array}{r}0.8261249 \\
(0.00)\end{array}$ & \multirow[t]{4}{*}{0.2168502} & 0.3738837 & 2.689673 & Increasing & \multirow[t]{4}{*}{ 2006-02-17 } \\
\hline & $G P H_{0.8}$ & 1.040507 & & 0.2031622 & 4.818530 & Cannot reject $H_{0}$ & \\
\hline & & $(0.00)$ & & 0.2931399 & 3.398623 & Increasing & \\
\hline & $A R F I M A$ & $\begin{array}{r}0.912256 \\
(0.00) \\
\end{array}$ & & 0.2980519 & 3.405067 & Increasing & \\
\hline \multicolumn{8}{|l|}{ Spain } \\
\hline \multirow[t]{3}{*}{$\overline{5 \text { Years }}$} & $G P H_{0.5}$ & $\begin{array}{r}0.7211466 \\
(0.00)\end{array}$ & \multirow[t]{3}{*}{0.2000173} & 0.4805613 & 2.021178 & Increasing & \multirow[t]{3}{*}{$2007-07-13$} \\
\hline & $G P H_{0.8}$ & $\begin{array}{r}1.013131 \\
(0.00)\end{array}$ & & 0.2215111 & 4.43305 & Increasing & \\
\hline & $A R F I M A$ & $\begin{array}{r}0.955147 \\
(0.00) \\
\end{array}$ & & 0.2638453 & 3.790605 & Increasing & \\
\hline \multirow[t]{3}{*}{7 Years } & $G P H_{0.5}$ & $\begin{array}{r}0.7753959 \\
(0.00)\end{array}$ & \multirow[t]{3}{*}{0.216574} & 0.4232451 & 2.312308 & Increasing & \multirow[t]{3}{*}{ 2008-04-11 } \\
\hline & $G P H_{0.8}$ & $\begin{array}{r}1.009249 \\
(0.00)\end{array}$ & & 0.2241996 & 4.383334 & Increasing & \\
\hline & $A R F I M A$ & $\begin{array}{r}0.958343 \\
(0.00) \\
\end{array}$ & & 0.2613928 & 3.821458 & Increasing & \\
\hline \multirow[t]{6}{*}{10 Years } & $G P H_{0.5}$ & 0.7942096 & \multirow[t]{6}{*}{0.4701436} & 0.4044981 & 2.443771 & Cannot reject $H_{0}$ & \multirow{6}{*}{ 2008-04-11 } \\
\hline & & $(0.00)$ & & 0.5041109 & 1.982196 & Increasing & \\
\hline & $G P H_{0.8}$ & 1.048539 & & 0.1979846 & 4.944093 & Cannot reject $H_{0}$ & \\
\hline & & $(0.00)$ & & 0.2872943 & 3.468063 & Cannot reject $H_{0}$ & \\
\hline & $A R F I M A$ & 0.960283 & & 0.2599108 & 3.840383 & Cannot reject $H_{0}$ & \\
\hline & & $(0.00)$ & & 0.3540306 & 2.834345 & Cannot reject $H_{0}$ & \\
\hline \multicolumn{8}{|l|}{ France } \\
\hline \multirow[t]{3}{*}{5 Years } & $G P H_{0.5}$ & $\begin{array}{r}0.9975786 \\
(0.00)\end{array}$ & \multirow[t]{3}{*}{0.2206679} & 0.23241 & 4.240527 & Increasing & \multirow[t]{3}{*}{$2007-07-13$} \\
\hline & $G P H_{0.8}$ & $\begin{array}{r}0.9097598 \\
(0.00)\end{array}$ & & 0.3001158 & 3.383716 & Increasing & \\
\hline & $A R F I M A$ & $\begin{array}{r}0.967148 \\
(0.00) \\
\end{array}$ & & 0.2547067 & 3.908633 & Increasing & \\
\hline \multirow[t]{3}{*}{7 Years } & $G P H_{0.5}$ & $\begin{array}{r}0.9631191 \\
(0.00)\end{array}$ & \multirow[t]{3}{*}{0.2340448} & 0.2577532 & 3.868331 & Increasing & \multirow[t]{3}{*}{$2008-05-16$} \\
\hline & $G P H_{0.8}$ & $\begin{array}{r}0.9295885 \\
(0.00)\end{array}$ & & 0.2839416 & 3.555807 & Increasing & \\
\hline & $A R F I M A$ & $\begin{array}{r}0.925204 \\
(0.00) \\
\end{array}$ & & 0.2874744 & 3.517192 & Increasing & \\
\hline \multirow[t]{3}{*}{10 Years } & $G P H_{0.5}$ & $\begin{array}{r}0.9950248 \\
(0.00)\end{array}$ & 0.2381037 & $\begin{array}{r}0.234232 \\
0.3270063\end{array}$ & $\begin{array}{r}4.21054 \\
3.053236\end{array}$ & $\begin{array}{r}\text { Cannot reject } H_{0} \\
\text { Increasing }\end{array}$ & $2007-07-13$ \\
\hline & $G P H_{0.8}$ & $\begin{array}{r}1.009488 \\
(0.00)\end{array}$ & & $\begin{array}{r}0.2240332 \\
0.31608\end{array}$ & $\begin{array}{l}4.386367 \\
3.154838\end{array}$ & $\begin{array}{r}\text { Cannot reject } H_{0} \\
\text { Increasing }\end{array}$ & \\
\hline & $A R F I M A$ & $\begin{array}{r}0.867576 \\
(0.00) \\
\end{array}$ & & 0.3361941 & 3.029541 & Increasing & \\
\hline
\end{tabular}

The table reports the results of the test procedure proposed by Sibbertsen and Kruse (2009) applied to the spreads. To determine $d$ under $H_{0}$ the GPH estimator (bandwiths 0.5 and 0.8 ) and the ARFIMA model are employed ( $p$-values are reported in parantheses). The test statistic (reported in the first lines) remains constant for every $d$. If $H_{0}$ cannot be rejected the significance level is set to 0.1 . 
Table A.3: Estimation results for ARFIMA models (Germany-Italy)

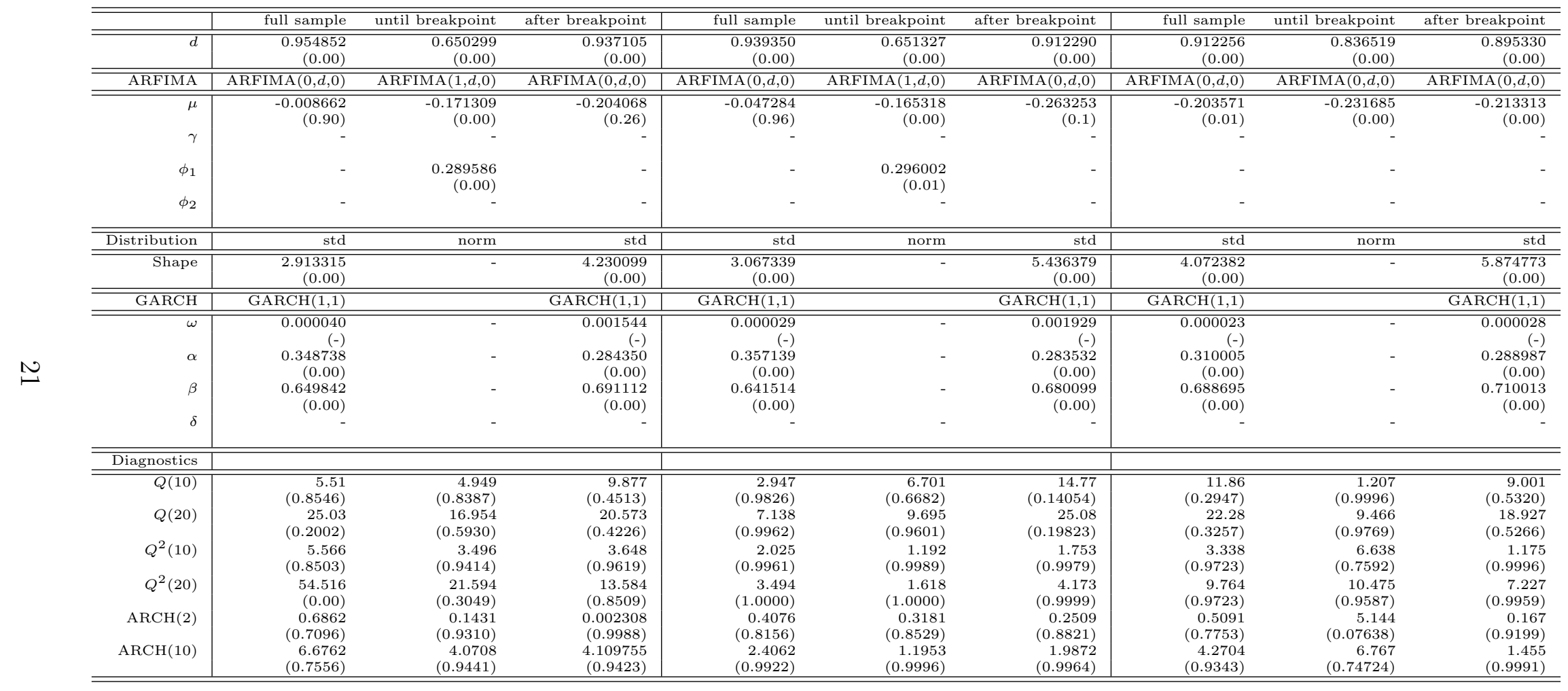

The table reports the estimation results of the $\operatorname{ArFimA}(p, d, q)-(\operatorname{GARCH}(1,1))$ models for the bond yield spreads of Germany and Italy. From left to right: 5,7 and 10 years with full- and sub-samples. $d$ is the degree of integration, $\mu$ is a constant, $\gamma$ is a linear trend, $\phi_{p}$ are AR parts, 'Shape' is the estimated shape of the used distribution, $\omega$ is a constant and $\alpha, \beta$ and $\delta$ are estimated coefficients of the GARCH equation. $Q(p)\left(Q^{2}(p)\right)$ is the test statistic of the Ljung-Box test applied to the (squared) residuals and $\operatorname{ARCH}(p)$ is the ARCH-LM test statistic with $p$ lags; $p$-values are reported in parentheses. 
Table A.4: Estimation results for ARFIMA models (Germany-Spain).

\begin{tabular}{|c|c|c|c|c|c|c|c|c|c|}
\hline & full sample & until breakpoint & after breakpoint & full sample & until breakpoint & after breakpoint & $\begin{array}{l}\text { full sample } \\
\end{array}$ & until breakpoint & after breakpoint \\
\hline$\overline{c d}$ & $\begin{array}{r}0.955147 \\
(0.00)\end{array}$ & $\begin{array}{r}0.613805 \\
(0.00)\end{array}$ & $\begin{array}{r}0.928806 \\
(0.00)\end{array}$ & $\begin{array}{r}0.958343 \\
(0.00)\end{array}$ & $\begin{array}{r}0.685293 \\
(0.00)\end{array}$ & $\begin{array}{r}0.908827 \\
(0.00)\end{array}$ & $\begin{array}{r}0.960283 \\
(0.00)\end{array}$ & $\begin{array}{r}0.923128 \\
(0.00)\end{array}$ & $\begin{array}{r}0.888529 \\
(0.00)\end{array}$ \\
\hline ARFIMA & ARFIMA $(0, d, 0)$ & ARFIMA $(1, d, 0)$ & ARFIMA $(0, d, 0)$ & (ARFIMA $(0, d, 0)$ & (ARFIMA $(1, d, 0)$ & ARFIMA $(0, d, 0)$ & $\overline{\text { ARFIMA }(0, d, 0)}$ & PARFIMA $(0, d, 0)$ & 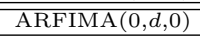 \\
\hline 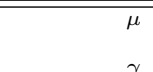 & $\begin{array}{r}0.092247 \\
(0.66)\end{array}$ & $\begin{array}{r}-0.097869 \\
(0.01)\end{array}$ & $\begin{array}{r}-0.073052 \\
(0.65)\end{array}$ & $\begin{array}{r}0.037906 \\
(0.94)\end{array}$ & $\begin{array}{r}-0.104572 \\
(0.00)\end{array}$ & $\begin{array}{r}-0.132530 \\
(0.35)\end{array}$ & $\begin{array}{r}-0.138050 \\
(0.07)\end{array}$ & $\begin{array}{r}-0.177790 \\
(0.00)\end{array}$ & $\begin{array}{r}-0.334622 \\
(0.01)\end{array}$ \\
\hline $\begin{array}{l}\phi_{1} \\
\phi_{2}\end{array}$ & - & $\begin{array}{r}0.352715 \\
(0.01)\end{array}$ & - & - & $\begin{array}{r}0.291573 \\
(0.01)\end{array}$ & - & - & - & - \\
\hline$\overline{\text { Distribution }}$ & $\overline{\text { std }}$ & "norm & $\overline{\text { std }}$ & std & "norm & std & std & $\begin{array}{ll}\text { norm } \\
\end{array}$ & std \\
\hline Shape & $\begin{array}{r}2.725074 \\
(0.00)\end{array}$ & $\overline{-1}$ & $\begin{array}{r}4.305896 \\
(0.00)\end{array}$ & $\begin{array}{r}2.890988 \\
(0.00)\end{array}$ & - & $\begin{array}{r}.394264 \\
(0.00)\end{array}$ & $\begin{array}{r}3.034710 \\
(0.00)\end{array}$ & 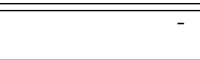 & $\begin{array}{r}5.198461 \\
(0.00)\end{array}$ \\
\hline GARCH & GJR-GARCH $(1,1)$ & & GJR-GARCH $(1,1)$ & GARCH $(1,1)$ & & GARCH $(1,1)$ & GARCH $(1,1)$ & GARCH $(1,1)$ & GARCH $(1,1)$ \\
\hline $\begin{array}{l}\omega \\
\alpha \\
\beta \\
\delta\end{array}$ & $\begin{array}{r}0.000034 \\
(-) \\
0.220791 \\
(0.00) \\
0.611092 \\
(0.00) \\
0.334233 \\
(0.01) \\
\end{array}$ & $\begin{array}{l}- \\
-\end{array}$ & $\begin{array}{r}0.000088 \\
(-) \\
0.154134 \\
(0.00) \\
0.685885 \\
(0.00) \\
0.317408 \\
(0.00) \\
\end{array}$ & $\begin{array}{r}0.000026 \\
(-) \\
0.388742 \\
(0.00) \\
0.610258 \\
(0.00)\end{array}$ & $\begin{array}{l}- \\
-\end{array}$ & $\begin{array}{r}0.001213 \\
(-) \\
0.337034 \\
(0.00) \\
0.643275 \\
(0.00)\end{array}$ & $\begin{array}{r}0.000022 \\
(-) \\
0.358744 \\
(0.00) \\
0.640256 \\
(0.00)\end{array}$ & $\begin{array}{r}0.000031 \\
(-) \\
0.254048 \\
(0.00) \\
0.658679 \\
(0.00)\end{array}$ & $\begin{array}{r}0.000022 \\
(-) \\
0.089687 \\
(0.00) \\
0.842022 \\
(0.00)\end{array}$ \\
\hline \multicolumn{10}{|l|}{ Diagnostics } \\
\hline$Q(10)$ & $\begin{array}{l}6.863 \\
\end{array}$ & $\begin{array}{l}13.53 \\
\end{array}$ & $\begin{array}{ll}18.00 \\
\end{array}$ & $\begin{array}{ll}29.41 \\
\end{array}$ & 16.40 & 15.65 & 4.906 & ב7.407 & 111.00 \\
\hline & $(0.73834)$ & & & $(0.001070)$ & & $(0.1101)$ & & $(0.6865)$ & \\
\hline$Q(20)$ & 35.419 & 28.87 & 28.77 & $\begin{array}{r}44.89 \\
\end{array}$ & 23.41 & 23.01 & 13.068 & 21.031 & 16.74 \\
\hline$Q^{2}(10)$ & $\begin{array}{r}(0.01798) \\
0.8132\end{array}$ & $\begin{array}{r}(0.06803) \\
5.662\end{array}$ & $\begin{array}{r}(0.09235) \\
7.307\end{array}$ & $(0.001143)$ & $\begin{array}{l}(0.21993) \\
1.712\end{array}$ & $\begin{array}{r}(0.2882) \\
12.11\end{array}$ & $\begin{array}{l}(0.8744) \\
4.932\end{array}$ & $\begin{array}{r}(0.3953) \\
2.992\end{array}$ & $\begin{array}{r}(0.6701) \\
3.947\end{array}$ \\
\hline & $(0.9999)$ & $(0.7733)$ & $(0.6961)$ & $(0.2753)$ & (0.9953) & $(0.2778)$ & $(0.8957)$ & $(0.9816)$ & (0.9497) \\
\hline$Q^{2}(20)$ & 9.5008 & 11.149 & 9.175 & 26.77 & 4.525 & 15.55 & 6.447 & 5.158 & 7.315 \\
\hline & $(0.9763)$ & $(0.9187)$ & $(0.9808)$ & $(0.1418)$ & (0.9997) & $(0.7443)$ & $(0.9981)$ & $(0.9996)$ & $(0.9955)$ \\
\hline $\operatorname{ARCH}(2)$ & 0.1619 & 0.2218 & 0.6499 & 0.1003 & 0.001194 & 5.432 & 1.026 & 0.6051 & 1.454 \\
\hline & $(0.9223)$ & $(0.8950)$ & $(0.7226)$ & $(0.9511)$ & $(0.9994)$ & $(0.06614)$ & $(0.5986)$ & $(0.7389)$ & $(0.4834)$ \\
\hline $\mathrm{ARCH}(10)$ & 0.8994 & 3.6550 & 7.1762 & 11.5921 & 1.934522 & 11.712 & 5.996 & 3.7259 & 4.139 \\
\hline & $\begin{array}{l}0.0999) \\
(0.999)\end{array}$ & $(0.9616)$ & $(0.7087)$ & $(0.3133)$ & $(0.9968)$ & $(0.3048)$ & $(0.8156)$ & $(0.9589)$ & $(0.9409)$ \\
\hline
\end{tabular}

The table reports the estimation results of the $\operatorname{ARFimA}(p, d, q)-(\operatorname{GARCH}(1,1))$ models for the bond yield spreads of Germany and Spain. From left to right: 5,7 and 10 years with full- and sub-samples. $d$ is the degree of integration, $\mu$ is a constant, $\gamma$ is a linear trend, $\phi_{p}$ are AR parts, 'Shape' is the estimated shape of the used distribution, $\omega$ is a constant and $\alpha, \beta$ and $\delta$ are estimated coefficients of the GARCH equation. $Q(p)\left(Q^{2}(p)\right)$ is the test statistic of the Ljung-Box test applied to the (squared) residuals and $\operatorname{ARCH}(p)$ is the ARCH-LM test statistic with $p$ lags; $p$-values are reported in parentheses. 
Table A.5: Estimation results for ARFIMA models (Germany-France).

\begin{tabular}{|c|c|c|c|c|c|c|c|c|c|}
\hline & full sample & until breakpoint & after breakpoint & full sample & until breakpoint & after breakpoint & full sample & until breakpoint & after breakpoint \\
\hline$\overline{c d}$ & $\begin{array}{r}0.967148 \\
(0.00) \\
\end{array}$ & $\begin{array}{r}0.384572 \\
(0.06) \\
\end{array}$ & $\begin{array}{r}0.889150 \\
(0.00) \\
\end{array}$ & $\begin{array}{r}0.925204 \\
(0.00) \\
\end{array}$ & $\begin{array}{r}0.294767 \\
(0.00) \\
\end{array}$ & $\begin{array}{r}0.83473 \\
(0.00) \\
\end{array}$ & $\begin{array}{r}0.867576 \\
(0.00) \\
\end{array}$ & $\begin{array}{r}0.815206 \\
(0.00) \\
\end{array}$ & $\begin{array}{r}0.819492 \\
(0.00) \\
\end{array}$ \\
\hline ARFIMA & ARFIMA $(0, d, 0)$ & ARFIMA $(1, d, 0)$ & ARFIMA $(0, d, 0)$ & ARFIMA $(0, d, 0)$ & ARFIMA $(1, d, 0)$ & ARFIMA $(0, d, 0)$ & ARFIMA $(0, d, 0)$ & ARFIMA $(0, d, 0)$ & (PRFIMA $(0, d, 0)$ \\
\hline 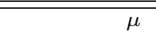 & " - & 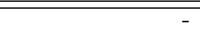 & ב- & " - & " - & " - & - & ב- & \\
\hline$\gamma$ & - & - & - & - & - & - & - & - & - \\
\hline$\phi_{1}$ & - & $\begin{array}{r}0.585348 \\
(0.12)\end{array}$ & - & - & $\begin{array}{r}0.705254 \\
(0.00)\end{array}$ & - & - & - & - \\
\hline$\phi_{2}$ & - & & - & - & & - & - & - & - \\
\hline Distribution & $\begin{array}{l}\text { std } \\
\end{array}$ & "norm & std & std & $\begin{array}{ll}\text { norm } \\
\end{array}$ & $\begin{array}{l}\text { std } \\
\end{array}$ & 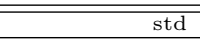 & $\begin{array}{ll}\text { norm } \\
\end{array}$ & $\overline{\text { std }}$ \\
\hline Shape & $\begin{array}{r}2.411629 \\
(0.00) \\
\end{array}$ & - & $\begin{array}{r}3.325520 \\
(0.00) \\
\end{array}$ & $\begin{array}{r}2.495413 \\
(0.00) \\
\end{array}$ & - & $\begin{array}{r}4.80375 \\
(0.00) \\
\end{array}$ & $\begin{array}{r}.001733 \\
(0.00) \\
\end{array}$ & - & $\begin{array}{r}5.110759 \\
(0.00) \\
\end{array}$ \\
\hline GARCH & GARCH $(1,1)$ & & GARCH $(1,1)$ & GARCH $(1,1)$ & & GARCH $(1,1)$ & GARCH $(1,1)$ & & GARCH $(1,1)$ \\
\hline $\begin{array}{l}\omega \\
\alpha \\
\beta \\
\delta\end{array}$ & $\begin{array}{r}0.000009 \\
(-) \\
0.137270 \\
(0.00) \\
0.860366 \\
(0.00)\end{array}$ & $\begin{array}{l}- \\
- \\
-\end{array}$ & $\begin{array}{r}0.000173 \\
(-) \\
0.332789 \\
(0.00) \\
0.642098 \\
(0.00)\end{array}$ & $\begin{array}{r}0.000009 \\
(-) \\
0.174961 \\
(0.00) \\
0.822067 \\
(0.00)\end{array}$ & $\begin{array}{l}- \\
- \\
-\end{array}$ & $\begin{array}{r}0.00028 \\
(-) \\
0.22509 \\
(0.00) \\
0.73608 \\
(0.00)\end{array}$ & $\begin{array}{r}0.000004 \\
(-) \\
0.162787 \\
(0.00) \\
0.835817 \\
(0.00) \\
-\end{array}$ & $\begin{array}{l}- \\
- \\
- \\
-\end{array}$ & 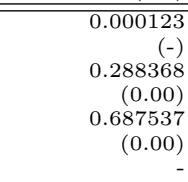 \\
\hline \multicolumn{10}{|l|}{$\begin{array}{l}\text { Diagnostics } \\
\end{array}$} \\
\hline$\overline{Q(10)}$ & 7.462 & 7.298 & 4.133 & 7.154 & 8.953 & 12.69 & 14.92 & 18.08 & 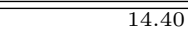 \\
\hline & $(0.6813)$ & $(0.6061)$ & $(0.9412)$ & $(0.7108)$ & $(0.44163)$ & $(0.2414)$ & $(0.1352)$ & $(0.05367)$ & $(0.1556)$ \\
\hline$Q(20)$ & $\begin{array}{r}10.048 \\
(0.9673)\end{array}$ & $\begin{array}{r}12.323 \\
(0.8714)\end{array}$ & $\begin{array}{r}12.337 \\
(0.9040)\end{array}$ & $\begin{array}{r}19.631 \\
(0.4812)\end{array}$ & $\begin{array}{r}27.739 \\
(0.08859)\end{array}$ & 16.16 & 21.97 & $\begin{array}{r}34.03 \\
(0.02594)\end{array}$ & 19.49 \\
\hline$Q^{2}(10)$ & $\begin{array}{r}(0.9673) \\
1.611\end{array}$ & $\begin{array}{r}(0.814) \\
4.792\end{array}$ & $\begin{array}{r}(0.9040) \\
4.677\end{array}$ & $\begin{array}{r}0.412) \\
5.686\end{array}$ & $\begin{array}{r}(0.08059) \\
2.82\end{array}$ & $\begin{array}{r}(0.009) \\
10.77\end{array}$ & $\begin{array}{r}(0.3420) \\
2.303\end{array}$ & $\begin{array}{r}(0.02594) \\
6.601\end{array}$ & $\begin{array}{r}(0.491) \\
3.473\end{array}$ \\
\hline & $(0.9985)$ & $(0.8520)$ & $(0.9117)$ & $(0.8409)$ & $(0.9710)$ & $(0.3759)$ & $(0.9934)$ & $(0.7625)$ & $(0.9680)$ \\
\hline$Q^{2}(20)$ & 2.744 & 10.647 & 14.902 & 21.279 & 20.60 & 16.86 & 6.519 & 20.502 & 6.218 \\
\hline & $(1.0000)$ & $(0.9352)$ & $(0.7820)$ & $(0.3809)$ & $(0.3595)$ & $(0.6620)$ & $(0.9980)$ & $(0.4269)$ & $(0.9986)$ \\
\hline $\mathrm{ARCH}(2)$ & 0.1721 & 0.8213 & 0.5616 & 1.556 & 0.3 & 1.478 & 0.4 & 2.650 & 0.5630 \\
\hline & $(0.9175)$ & $(0.6632)$ & $(0.7552)$ & $(0.4593)$ & $(0.8445)$ & $(0.4777)$ & $(0.8021)$ & $(0.2658)$ & $(0.7546)$ \\
\hline $\mathrm{ARCH}(10)$ & 1.7870 & 5.0997 & 5.9373 & 7.225 & 2.7419 & 9.656 & 2.6803 & 6.272 & 4.2265 \\
\hline & $(0.9977)$ & $(0.8844)$ & $(0.8205)$ & $(0.7040)$ & $(0.9869)$ & $(0.4712)$ & $(0.9880)$ & $(0.7920)$ & $(0.9365)$ \\
\hline
\end{tabular}

The table reports the estimation results of the $\operatorname{ARFimA}(p, d, q)-(\operatorname{GARCH}(1,1))$ models for the bond yield spreads of Germany and France. From left to right: 5,7 and 10 years with full- and sub-samples. $d$ is the degree of integration, $\mu$ is a constant, $\gamma$ is a linear trend, $\phi_{p}$ are AR parts, 'Shape' is the estimated shape of the used distribution, $\omega$ is a constant and $\alpha, \beta$ and $\delta$ are estimated coefficients of the GARCH equation. $Q(p)\left(Q^{2}(p)\right)$ is the test statistic of the Ljung-Box test applied to the (squared) residuals and $\operatorname{ARCH}(p)$ is the ARCH-LM test statistic with $p$ lags; $p$-values are reported in parentheses. 
Table A.6: Results of the GPH estimator

\begin{tabular}{|c|c|c|c|c|}
\hline & $\begin{array}{r}G P H_{0.5} \\
\text { until breakpoint }\end{array}$ & $\begin{array}{r}G P H_{0.5} \\
\text { after breakpoint }\end{array}$ & $\begin{array}{r}G P H_{0.8} \\
\text { until breakpoint }\end{array}$ & $\begin{array}{r}G P H_{0.8} \\
\text { after breakpoint }\end{array}$ \\
\hline \multicolumn{5}{|l|}{ Italy } \\
\hline 5 Years & $\begin{array}{r}0.7432462 \\
(0.003)\end{array}$ & $\begin{array}{r}0.9814623 \\
(0.009)\end{array}$ & $\begin{array}{r}0.7912064 \\
(0.000)\end{array}$ & $\begin{array}{r}1.024969 \\
(0.000)\end{array}$ \\
\hline 7 Years & $\begin{array}{r}0.8431404 \\
(0.003)\end{array}$ & $\begin{array}{r}1.024401 \\
(0.002)\end{array}$ & $\begin{array}{r}0.7770464 \\
\quad(0.000)\end{array}$ & $\begin{array}{r}1.052399 \\
(0.000)\end{array}$ \\
\hline 10 Years & $\begin{array}{r}1.031385 \\
(0.000) \\
\end{array}$ & $\begin{array}{r}1.064351 \\
(0.000) \\
\end{array}$ & $\begin{array}{r}0.9573432 \\
(0.000) \\
\end{array}$ & $\begin{array}{r}1.045143 \\
(0.000) \\
\end{array}$ \\
\hline \multicolumn{5}{|l|}{ Spain } \\
\hline 5 Years & $\begin{array}{r}0.5750409 \\
(0.007)\end{array}$ & $\begin{array}{r}0.9016718 \\
(0.000)\end{array}$ & $\begin{array}{r}0.8339518 \\
(0.000)\end{array}$ & $\begin{array}{r}1.083345 \\
(0.000)\end{array}$ \\
\hline 7 Years & $\begin{array}{r}0.6703103 \\
(0.000)\end{array}$ & $\begin{array}{r}0.9692609 \\
(0.000)\end{array}$ & $\begin{array}{r}0.9032905 \\
(0.000)\end{array}$ & $\begin{array}{r}1.086441 \\
(0.000)\end{array}$ \\
\hline 10 Years & $\begin{array}{r}0.8354849 \\
(0.001) \\
\end{array}$ & $\begin{array}{r}0.9970904 \\
(0.000) \\
\end{array}$ & $\begin{array}{r}0.8250589 \\
(0.000) \\
\end{array}$ & $\begin{array}{r}1.097875 \\
(0.000) \\
\end{array}$ \\
\hline \multicolumn{5}{|l|}{ France } \\
\hline 5 Years & $\begin{array}{r}0.1342603 \\
(0.5255)\end{array}$ & $\begin{array}{r}1.119642 \\
(0.000)\end{array}$ & $\begin{array}{r}0.7072837 \\
(0.000)\end{array}$ & $\begin{array}{r}0.842274 \\
(0.000)\end{array}$ \\
\hline 7 Years & $\begin{array}{r}0.5212631 \\
(0.0142)\end{array}$ & $\begin{array}{r}1.108931 \\
(0.000)\end{array}$ & $\begin{array}{r}0.8297926 \\
(0.000)\end{array}$ & $\begin{array}{r}0.8553365 \\
(0.000)\end{array}$ \\
\hline 10 Years & $\begin{array}{r}0.6408966 \\
(0.0365)\end{array}$ & $\begin{array}{r}1.297049 \\
(0.000)\end{array}$ & $\begin{array}{r}0.7112324 \\
(0.000)\end{array}$ & $\begin{array}{r}0.9456978 \\
(0.000)\end{array}$ \\
\hline
\end{tabular}

The table reports the results of the GPH estimator applied to spreads with bandwidths of 0.5 and 0.8 until and after the estimated breakpoints. 


\section{Appendix B. Figures}

Figure B.1: Spreads between EMU Government Bonds
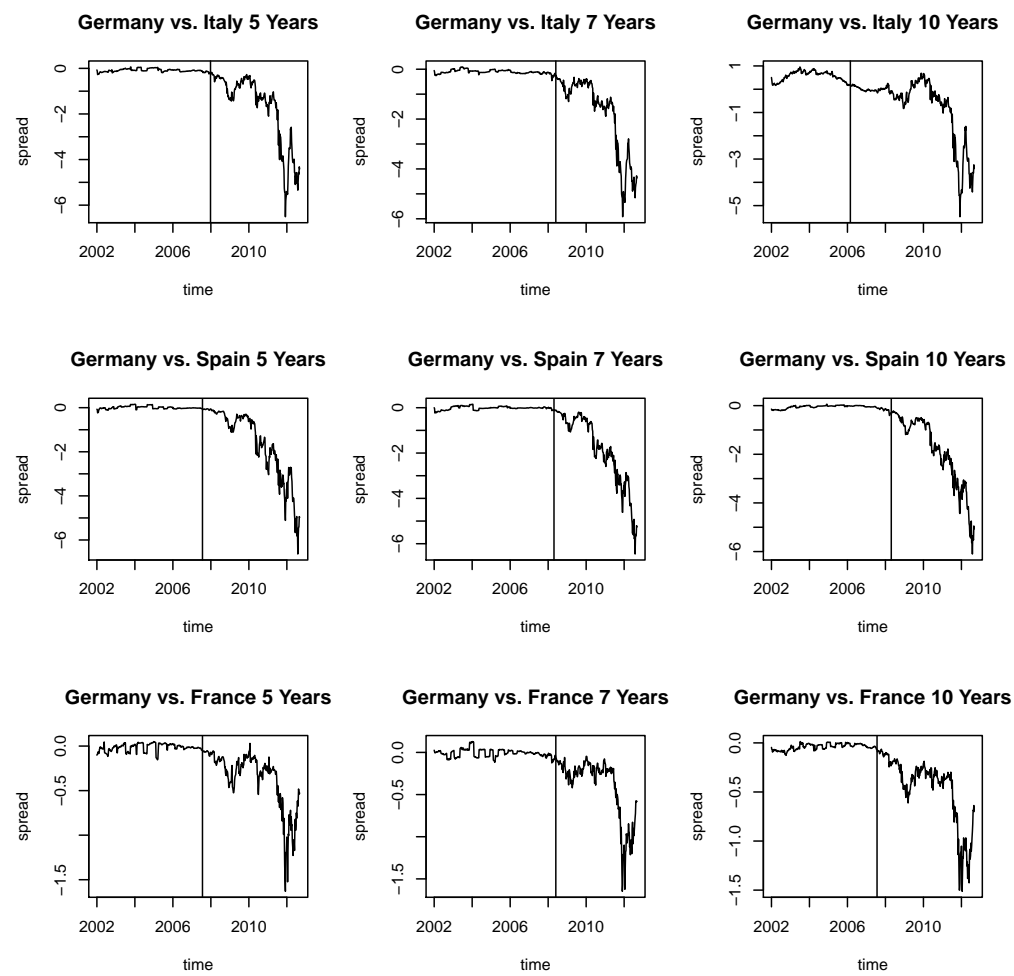

The figure shows the spreads of the considered government bond yields. The line indicates the estimated breakpoint. 
Figure B.2: Spreads between EMU Government Bonds in $d$ differences

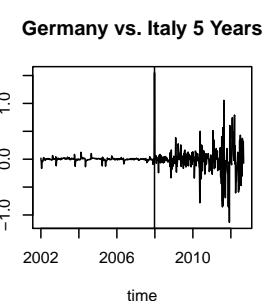

Germany vs. Spain 5 Years

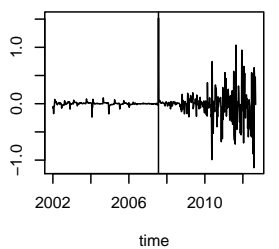

Germany vs. France 5 Years

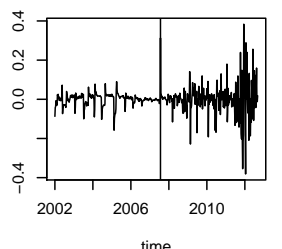

Germany vs. Italy 7 Years

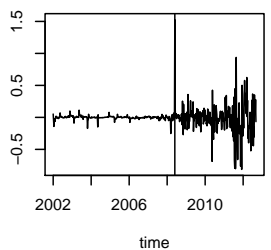

Germany vs. Spain 7 Years

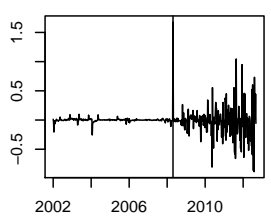

time
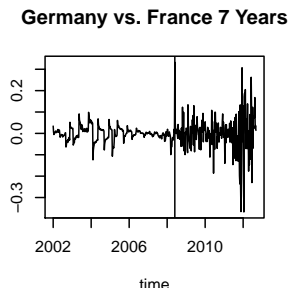

Germany vs. Italy 10 Years

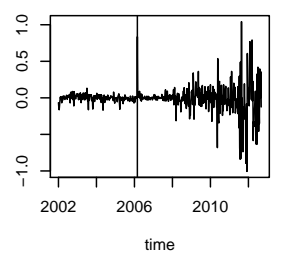

Germany vs. Spain 10 Years

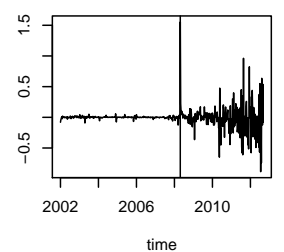

Germany vs. France 10 Years

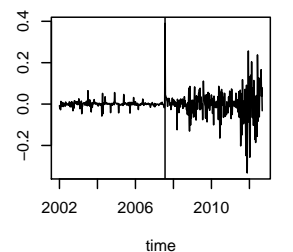

The figure shows the spreads in $d$ differences of the considered government bond yields. $d$ is determined by the ARFIMA model. The line indicates the estimated breakpoint. 


\section{References}

Apergis, N., Mamatzakis, E., Staikouras, C., 2011. Testing for regime changes in greek sovereign debt crisis. International Advances in Economic Research 17, 258-273.

Bajo-Rubio, O., Montávez-Garcés, M., 2002. Was there monetary autonomy in europe on the eve of emu? the german dominance hypothesis re-examined. Journal of Applied Economics 5, 185-207.

Basse, T., 2006. Floating exchange rates and inflation in germany: Are external shocks really irrelevant? Economics Letters 93, 393-397.

Basse, T., Friedrich, M., Kleffner, A., 2012. Italian government debt and sovereign credit risk: An empirical exploration and some thoughts about consequences for european insurers. Zeitschrift für die gesamte Versicherungswissenschaft 101, 571-579.

Baum, C., Barkoulas, J., 2006. Dynamics of intra-ems interest rate linkages. Journal of Money, Credit, and Banking 38, 469-482.

Becker, B., Hall, S., 2007. Measuring convergence of the new member countries exchange rates to the euro. Journal of Financial Transformation 19, 20-25.

Camarero, M., Ordonez, J., Tamarit, C., 2002. Tests for interest rate convergence and structural breaks in the ems: Further analysis. Applied Financial Economics 12, 447-456.

Cooper, R., 1984. The international monetary system: Forty years after bretton woods - is there a need for reform?, Federal Reserve Bank of Boston. pp. 21-39.

Cuñado, J., Gil-Alana, L., De Gracia, F., 2005. A test for rational bubbles in the nasdaq stock index: a fractionally integrated approach. Journal of Banking \& Finance 29, 2633-2654.

De Haan, J., Pilat, D., Zelhorst, D., 1991. On the relationship between dutch and german interest rates. De Economist 139, 550-565.

Flood, R., Rose, A., 2002. Uncovered interest parity in crisis. IMF Staff Papers 49, 252-266. 
Fountas, S., Wu, J., 1998. Tests for interest rate convergence and structural breaks in the ems. Applied Financial Economics 8, 127-132.

Frömmel, M., Kruse, R., 2009. Interest rate convergence in the ems prior to european monetary union. CREATES Research Paper 23.

Frömmel, M., Kruse, R., 2012. Testing for a rational bubble under long memory. Quantitative Finance 12, 1723-1732.

Geweke, J., Porter-Hudak, S., 1983. The estimation and application of long memory time series models. Journal of Time Series Analysis 4, 221-238.

Glosten, L., Jagannathan, R., Runkle, D., 1993. On the relation between the expected value and the volatility of the nominal excess return on stocks. Journal of Finance 48, 1779-1801.

Granger, C., Joyeux, R., 1980. An introduction to long-memory time series models and fractional differencing. Journal of Time Series Analysis 1, $15-29$.

Hassapis, C., Pittis, N., Prodromidis, K., 1999. Unit roots and granger causality in the ems interest rates: The german dominance hypothesis revisited. Journal of International Money and Finance 18, 47-73.

Hauser, M., 1997. Semiparametric and nonparametric testing for long memory: A monte carlo study. Empirical Economics 22, 247-271.

Heinen, F., Sibbertsen, P., Kruse, R., 2009. Forecasting long memory time series under a break in persistence. Technical Report 433. Universität Hannover, Wirtschaftswissenschaftliche Fakultät.

Jenkins, M., Madzharova, P., 2008. Real interest rate convergence under the euro. Applied Economics Letters 15, 473-476.

Johansen, S., Juselius, K., 1992. Testing structural hypotheses in a multivariate cointegration analysis of the ppp and the uip for uk. Journal of Econometrics 53, 211-244.

Kanas, A., 1997. The monetary exchange rate model within the erm: Cointegration tests and implications concerning the german dominance hypothesis. Applied Financial Economics 7, 587-598. 
Kirchgässner, G., Wolters, J., 1987. Us-european interest rate linkage: A time series analysis for west germany, switzerland, and the united states. Review of Economics and Statistics 69, 675-84.

Kleimeier, S., Sander, H., 2000. Regionalisation versus globalisation in european financial market integration: Evidence from co-integration analyses. Journal of Banking \& Finance 24, 1005-1043.

Kočenda, E., Kutan, A., Yigit, T., 2006. Pilgrims to the eurozone: How far, how fast? Economic Systems 30, 311-327.

Laopodis, N., 2008. Government bond market integration within european union. International Research Journal of Finance and Economics 19, 5676.

Leybourne, S., Kim, T., Smith, V., Newbold, P., 2003. Tests for a change in persistence against the null of difference-stationarity. Econometrics Journal 6, 291-311.

Leybourne, S., Taylor, R., Kim, T., 2007. Cusum of squares-based tests for a change in persistence. Journal of Time Series Analysis 28, 408-433.

Lund, J., 1999. A model for studying the effect of emu on european yield curves. European Finance Review 2, 321-363.

Martin, F., Waller, C., 2012. Sovereign debt: a modern greek tragedy. Federal Reserve Bank of St. Louis Review 94, 321-39.

Melander, O., Pant, M., Segoviano, M., Vamvakidis, A., 2011. Dancing spreads: Market assessment of contagion from the crisis in the euro periphery based on distress dependence analysis. International Advances in Economic Research 17, 347-363.

Pigott, C., 1993. International interest rate convergence: A survey of the issues and evidence. Federal Reserve Bank of New York Quarterly Review $18,24-37$.

Rose, A., 2007. Checking out: Exits from currency unions. Journal of Financial Transformation 19, 121-128.

Sibbertsen, P., Kruse, R., 2009. Testing for a break in persistence under long-range dependencies. Journal of Time Series Analysis 30, 263-285. 
Siklos, P., Wohar, M., 1997. Convergence in interest rates and inflation rates across countries and over time. Review of International Economics $5,129-141$.

Taylor, M., 1995. The economics of exchange rates. Journal of Economic Literature 33, 13-47. 